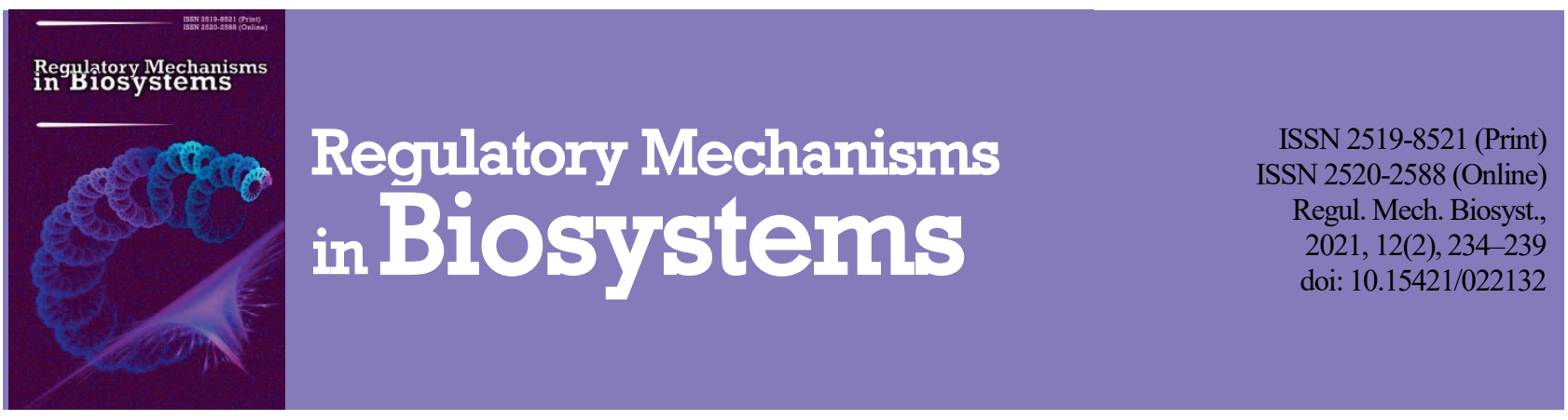

\title{
Effects of duration and conditions of storage on germination of seeds of Pedicularis sceptrum-carolinum (Orobanchaceae)
}

\author{
A. G. Lapirov*, E. A. Belyakov****, O. A. Lebedeva* \\ *Papanin Institute for Biology of Inland Waters, Borok, Russia \\ **Cherepovets State University, Cherepovets, Russia
}

Article info

Received 20.04.2021

Received in revised form 17.05.2021

Accepted 19.05.2021

Papanin Institute

for Biology of Inland Waters,

Borok, Nekouz district,

Yaroslavl Region,

152742, Russia.

Tel.: + 7-48-547-24-042

E-mail:a lapir@ibiw.ru

Cherepovets State University

Lunacharsky av., 5

Cherepovets, 162600, Russia

Tel.: +7-820-255-65-97.

E-mail:

eugenybeliakov@yandex.ru
Lapirov, A. G., Belyakov, E. A., \& Lebedeva, O. A. (2021). Effects of duration and conditions of storage on germination of seeds of Pedicularis sceptrum-carolinum (Orobanchaceae). Regulatory Mechanisms in Biosystems, 12(2), 234-239. doi:10.15421/022132

Choosing optimum conditions for plants of the Pedicularis genus to productively germinate and undergo the initial stages of development is currently a relevant problem in the search of solutions to successfully grow these taxa. For the experiments, seeds of Pedicularis sceptrum-carolinum L. (Lamiales, Orobanchaceae) were collected in the first decade of September in the vicinity of Chashnitskoe Lake. The study of specifics of germination of seeds and the initial stages of the development of $P$. sceptrum-carolinum was carried out in controlled laboratory conditions in a climate chamber with illumination (1,200-1,500 lux, photoperiod of $9 / 15$, temperature of $23-25^{\circ} \mathrm{C}$ ). After a month-long storage of seeds in their fruit capsules in the laboratory conditions, the greatest germination (83.3-93.3\%) was achieved after their subsequent dry maintenance (taken out of the fruits) in a refrigerator at the temperature of $+2 \ldots+3{ }^{\circ} \mathrm{C}$ for 3 or 6 months. Lower values of final germination were obtained after maintaining dry seeds at the temperature of $-24 \ldots-28^{\circ} \mathrm{C}$ for 3 months. Increasing periods of such storage up to six months led to decrease in the final germination and energy of germination. After-ripening lasting different periods provided lower values of the two most important parameters - final germination and energy of germination, even in cases of quite long periods of dry storage in the laboratory. The initial stages of the development of plants from seeds of $P$. sceptrumcarolinum, which had undergone 3-month stratification in a refrigerator, were studied during the period of $2.0(2.5)$ months in different conditions: Petri dishes on moistened filter paper, and in glass vessels with settled tap water, in soil in a plastic container (pure groups of sowed seeds) and also in soil sown together with seeds of Avena sativa L., with seeds put singly into a plastic block of 9 cassettes. The study revealed morphological differences in plants that had developed over the two-months growth, in each variant of the experiment. We recorded fragmentary development of haustorial hairs on the lateral roots of the plants in the pure sown group and also the haustorium in the group sown together with common oat. We achieved no further development and the plants died. The plants grew for a longer period (2.5 months) in the pure sown groups, which then died as well. The study we performed may be a basis for preparing successful introduction and cultivation of $P$. sceptrum-carolinum, which would be an important source of preservation of a species that raises concerns on account of the rapid decreases in its populations, narrowing of its range and rare occurrence.

Keywords: rare species; hemiparasites; generative reproduction; germination; Avena sativa; morphological differences.

\section{Introduction}

Genus Pedicularis L. (Orobanchaceae) is considered one of the largest genera of Angiospermae flower plants in the Northern Hemisphere (600 species around the globe) (Li et al., 2007; Ren \& Guan, 2008; Liu et al., 2013; Bruce et al., 2015) and is distinct by impressive morphological diversity (Ree, 2005). Species of this genus have great decorative and medicinal significance, and have long been a valuable material for biological studies (Li et al., 2007; Ren \& Guan, 2008).

Pedicularis sceptrum-carolinum L. is a hemiparasitic species with significantly fragmented geographic range in the Eurasia (Wróblewska, 2013; Wróblewska \& Mirski, 2018), inhabits tundra, forest and northern part of the steppe zone in the greater part of the Eurasia to North China and Japan. It occurs in waterlogged forests, wetlands with true sedges, on the banks of oligotrophic lakes, rivers, peatlands and wet meadows (Wróblewska, 2013; Petrova \& Pavlenko, 2017). According to Seregin (2011), beginning in the mid XX century up to now, a decrease has been observed in the number of places of occurrence of this species in Central Russia and Europe in general, which is related to the general eutrophication of the environment as a result of agricultural activities. At the same time, this process for $P$. sceptrum-carolinum is more intense than for a related species $P$. palustris L. (Seregin, 2011). In Europe, decrease in the range of this species is being attributed to changes in the practices of arable farming, amelioration of lands and natural successions in the peatlands (Magnes, 2003 - qtd. in: Wróblewska, 2013; Peregrym \& Peregrym, 2014). It is not accidental that in the regional Red Books of Russia (Voronin, 2015; Sorokin, 2016), P. sceptrum-carolinum is given 2nd or 3rd category of rarityspecies with decreasing numbers or rare species. According to Seregin (2011), this plant needs ubiquitous protection at both regional and federal levels. In a number of European countries, the species is classified as an endangered species, extremely rare or at the verge of extinction (Maglocký \& Feráková, 1993; Holub \& Procházka, 2000; Stachurska-Swakon et al., 2014).

P. sceptrum-carolinum is a short-rhizomatous species with adventitious roots, a lateral-haustorial grassy polycarpic plant, which sympodially grows with dicyclic orthotropic semi-rosette shoots of non-succulent type (Petrova \& Pavlenko, 2017). This plant presumably reproduces exclusively by seeds (Sorokin, 2016). Nonetheless, according to the Polish scientists, vegetative reproduction is possible, but occurs rarely by adventitious buds in the basal part of the plant which form daughter plants (Wróblews$\mathrm{ka}, 2013$ ). In contrast to the specialized studies of morphological structures of seeds of species of Pedicularis genus (including P. sceptrumcarolinum) (Liu et al., 2013; Danylevska \& Futorna, 2016), we found no such studies on germination of seeds of moor-king lousewort. Some data 
on this subject are available in an article about biology and morphologicalanatomical peculiarities of this species (Petrova \& Pavlenko, 2017). At the same time, seeds of most species of Pedicularis L. genus germinate slowly and unevenly and have a low percentage of germination (McDonough, 1970; Jensen, 2004; Li et al., 2007; Kirmizi et al., 2010). All this complicates successful cultivation of these taxa ( $\mathrm{Li}$ et al., 2007). At the same time, there is very little information concerning the germination requirements of seeds of species of this genus (Ren \& Guan, 2008). Furthermore, taking into account the high mortality rate of seedlings of various species of Pedicularis (Petri, 2005), the initial stages of the development of these plants are of special interest. Likewise, growth of these plants from seeds is quite difficult in laboratory conditions (Petrova \& Pavlenko, 2017; Kirillova, 2018).

Therefore, the objectives of our study were assessing the influence of duration and conditions of storage, after-ripening, dry stratification and low minus temperatures on germination of seeds of $P$. sceptrum-carolinum and analysis of the initial stages of the development of this species in different experimental conditions.

\section{Materials and methods}

Peculiarities of germination were studied on seeds collected in the first decade of September of 2017 in natural conditions of Chashnitskoe Lake (Yaroslavl Oblast, Rostov district, 56.936668 ${ }^{\circ} \mathrm{N}, 39.374617^{\circ} \mathrm{E}$ ). The plants grew along the edge of a waterlogged drainage ditch (of a former sand quarry) located along the south bank of the lake (Fig. 1) in a community with Marchantia sp., Equisetum hyemale L., E. scirpoides Michx., E. palustre L., Phragmites australis (Cav.) Trin. ex Steud, Salix myrsinifolia Salisb. and young plants of Populus tremula L. Vegetation was sparse; soil was large-grained sand.

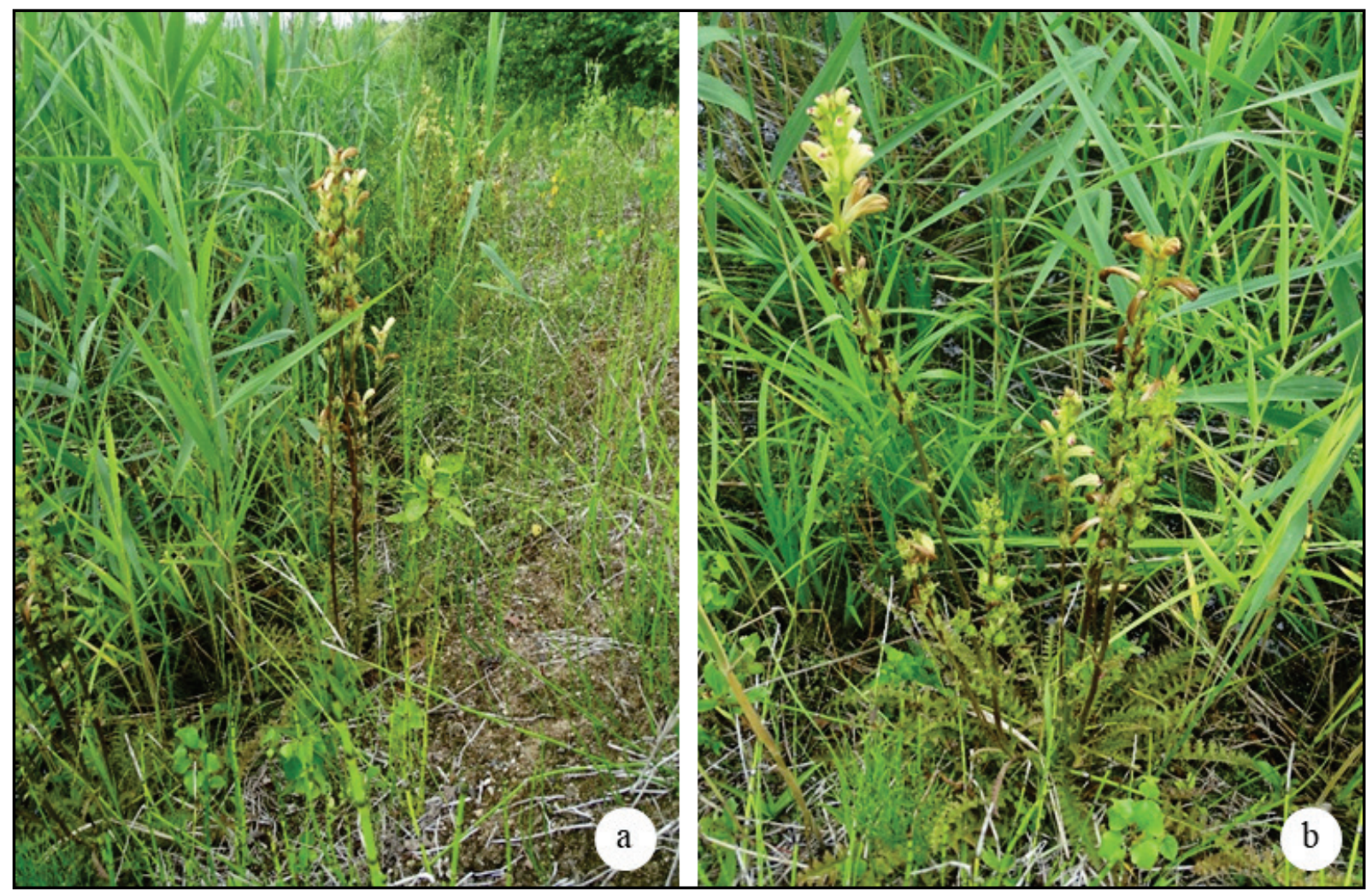

Fig. 1. Growing location of Pedicularis sceptrum-carolinum ( $a$ ) and appearance of the plant $(b)$

From the moment of collection up to the start of the experiment, the seeds were in the fruits - round dark brown capsules (about $1.0 \mathrm{~cm}$ in diameter) kept for one month in the laboratory conditions. Then, the seeds were taken out of the capsules and divided into three equal parts: one part of them was kept dry in Petri dishes on filter paper in laboratory conditions, the second one - in a refrigerator (temperature of $+2.5 \ldots+3.0^{\circ} \mathrm{C}$ ), and the third was put into a freezing chamber (the temperature of $-24 \ldots$ $\left.-28^{\circ} \mathrm{C}\right)$.

In the first experiment, seeds of $P$. sceptrum-carolinum were subjected to germination after a month, right after they had been taken out of the capsules - 01.10.2017; in the second, after maintenance in different conditions for 3 months - 01.01.2018; in the third - after storage for 6 months -01.04 .2018 .

Peculiarities of germination of seeds of $P$. sceptrum-carolinum were studied in controlled laboratory conditions in a climate chamber with illumination (luminostat, illuminance of 1,200-1,500 lux, photoperiod of 9/15, and $23-25{ }^{\circ} \mathrm{C}$ temperature). Seeds (20 to each) were put in Petri dishes on filter paper moistened with settled tap water $(\mathrm{pH}=8.2)$. The experiments were replicated three times; the experiments lasted for 60 days. Throughout the experiment, moisture on the filter paper was maintained at the same level.

Germination of the seeds was made according to the earlier described method (Belyakov \& Lapirov, 2015). We determined the following main parameters of germination (Shipley \& Parent, 1991): lag time (L) - time in days between the beginning of the experiment and start of germination; final germination (Gfin or G) - percentage of germinated seeds at the end of the experiment, which corresponds to the term "laboratory germinating capacity" in the domestic literature (Nikolaeva et al., 1999); energy of germination (E) - percentage of seeds germinated in 7 days; period of germination $(\mathrm{P})$ - number of days during which the seeds germinated.

To study the initial stages of the development, seeds of $P$. sceptrumcarolinum, after three month stratification in the refrigerator, were put into the climate chamber with illumination (in the same controlled conditions, see above) for monitoring further development of plants in various conditions: experiment 1 - in Petri dishes on moistened filter paper (20 seeds in each); experiment 2 - in glass vessels (of $300 \mathrm{~mL}$ capacity) with settled tap water ( 50 seeds in each); experiment 3 - in soil in the plastic container $(17.0 \times 12.0 \times 4.5 \mathrm{~cm})(100$ seeds $)$; experiment $4-$ in soil in a plastic container $(17.0 \times 12.0 \times 4.5 \mathrm{~cm})$ together with seeds of Avena sativa $\mathrm{L}$. (100 seeds of each species). Common oat was chosen randomly as a host plant for monitoring possible development of the haustoria on the roots of moor-king lousewort; experiment 5 - in soil, one seed in each plastic block consisting of 9 cassettes (size of each equaling $6.0 \times 5.0 \times$ $5.5 \mathrm{~cm})$.

Experiments 1 and 2 were replicated three times, experiments 3-5once, the duration of the experiment was 2.5 months. In experiments $3-5$, 
the seeds were put in soil at the depth of $1.0 \mathrm{~cm}$. In the experiments, we used universal, completely ready-made nutritive soil Terra vita (Nord Palp, Russia, 2018) prepared for growing seedlings. The soil was moistened when needed.

In each variant of the experiment, after 2.0 (2.5) months, we selected 5-10 plants. During the monitoring, we performed in-detail morphological analysis of separate elements of above-ground and underground spheres of the plants. We recorded the appearance of the embryonic root, development of cotyledon leaves, development of adventitious and lateral roots, emergence of the initial and subsequent true leaves, development of haustoria and haustorial hairs. To measure the main morphometric parameters of the plants, we used binocular microscopes MBS-10 (LZOS, Russia, 2010) and MSP-2 (LOMO-Microsystems, Russia, 2009) that have micrometric scales.

All obtained results were presented as mean value \pm standard deviation $(\mathrm{x} \pm \mathrm{SD})$. The data were analyzed in Statgraphics Centurion XVI (StatPoint Technologies, Inc., USA, 2010). Significance of the differences between the values $(\mathrm{P}<0.05)$ was determined using ANOVA in PAST (Hammer et al., 2001; Paleontological Statistics Software Package, Norway, 1999-2019). To determine significant differences, we used the Tukey test (with additions by Copenhaver \& Holland (1988) and Bonferroni correction)

\section{Results}

In the central part of European Russia, blooming of P. sceptrumcarolinum occurs in July, and the fruits ripen in late July-September. The fruits are round dark brown capsules of around $1.0-1.4 \mathrm{~cm}$ in diameter, gathered in whorls comprising 3-4 capsules. According to our data, the average number of the capsules in the inflorescences of this plant is
$16.6 \pm 6.2$. The number of seeds in the capsule of $P$. sceptrum-carolinum varies, on average equaling 94.8 \pm 53.7 . Large amounts of seeds are in the capsules located in the middle part of the inflorescence $(150.2 \pm$ 45.5 seeds). A total of $73.3 \pm 39.7$ seeds ripen in the capsules located in the lower part of the inflorescence, and $42.5 \pm 25.5$ in the upper part, and oftentimes the fruits have no time to form the ovary. Weight of 100 seeds is $0.024 \pm 0.003 \mathrm{~g}$. Seeds are elongated, light or dark brown, about 2.0$2.5 \mathrm{~mm}$ long, $1.0 \mathrm{~mm}$ wide. Our observations indicate that the dissemination of $P$. sceptrum-carolinum is stretched out in time, for when drying, the shoots that bear the capsules with remaining seeds do not fall over, and in conditions of intense wind, the remaining seeds continue to fall out of the hatched capsules. Analyzing the main parameters of germination of the seeds (Table 1), we should note that the highest values of two most important parameters - final germination and energy of germination were recorded after cold stratification of dry seeds in the refrigerator. Low enough values of these parameters were obtained when storing dry seeds in laboratory conditions, whereas 6 months storage in the refrigerator led to 3 -fold decrease compared with the three month period.

The general pattern of the development of plants out of seeds and initial stages of this process are presented below.

As our observations demonstrated, germination of $P$. sceptrumcarolinum is above-ground, hypocotylary. The first to emerge after a short period of absorbing water and swelling of seed (5-7 days) was the main root, which with growth was for some time under the protection of the external reticular sheath. Then, 2-3 days later, it comes through the reticular sheath. The main root of the seedling is white with sharpened end and indumenta of thin root hairs (sometimes they may be absent). Then, it was followed by the strong light green hypocotyl, separated from the main root by crown-like indumentum of thin semi-translucent hairs (on the root neck), the epicotyl was expressed poorly (Fig. 2).

Table 1

Main parameters of germination of seeds of Pedicularis sceptrum-carolinum $(\mathrm{x} \pm \mathrm{SD}, \mathrm{n}=20)$

\begin{tabular}{|c|c|c|c|c|c|c|c|}
\hline Parameters & $\begin{array}{l}\text { Seeds were kept in fruit } \\
\text { capsules in laboratory } \\
\text { conditions for } 1 \text { month }\end{array}$ & $\begin{array}{l}\text { Seeds were stored in } \\
\text { laboratory conditions } \\
\text { for } 3 \text { months }\end{array}$ & $\begin{array}{l}\text { Seeds were kept } \\
\text { in the fridge } \\
\text { for } 3 \text { months }\end{array}$ & $\begin{array}{l}\text { Seeds were kept } \\
\text { in freezing chamber } \\
\text { for } 3 \text { months }\end{array}$ & $\begin{array}{l}\text { Seeds were stored in } \\
\text { laboratory conditions } \\
\text { for } 6 \text { months }\end{array}$ & $\begin{array}{l}\text { Seeds were kept } \\
\text { in fridge for } \\
6 \text { months }\end{array}$ & $\begin{array}{l}\text { Seeds were kept } \\
\text { in freezing chamber } \\
\text { for } 6 \text { months }\end{array}$ \\
\hline $\mathrm{L}, 24 \mathrm{~h}$ & $6.33 \pm 2.44^{\mathrm{a}}$ & $6.33 \pm 2.44^{\mathrm{a}}$ & $4.67 \pm 0.89^{\mathrm{a}}$ & $4.33 \pm 0.44^{\mathrm{a}}$ & $8.50 \pm 0.50^{\mathrm{a}}$ & $8.00 \pm 0.00^{\mathrm{a}}$ & $5.67 \pm 1.56^{\mathrm{a}}$ \\
\hline $\mathrm{P}, 24 \mathrm{~h}$ & $9.00 \pm 5.33^{\mathrm{a}}$ & $5.33 \pm 2.80^{\mathrm{a}}$ & $12.67 \pm 3.56^{\mathrm{a}}$ & $13.33 \pm 4.22^{\mathrm{a}}$ & $3.50 \pm 2.50^{\mathrm{a}}$ & $8.00 \pm 0.00^{\mathrm{a}}$ & $7.00 \pm 1.33^{\mathrm{a}}$ \\
\hline $\mathrm{G}_{\mathrm{fin},} \%$ & $18.33 \pm 7.78^{\mathrm{a}}$ & $13.33 \pm 11.11^{\mathrm{a}}$ & $88.33 \pm 2.22^{\mathrm{ab}}$ & $70.00 \pm 13.33^{\mathrm{ab}}$ & $12.50 \pm 7.50^{\mathrm{a}}$ & $93.33 \pm 4.44^{\mathrm{ab}}$ & $25.00 \pm 3.33^{\mathrm{a}}$ \\
\hline $\mathrm{E}, \%$ & $13.33 \pm 4.44^{\mathrm{a}}$ & $11.67 \pm 8.89^{\mathrm{a}}$ & $80.00 \pm 3.33^{\mathrm{ab}}$ & $58.33 \pm 5.56^{\mathrm{b}}$ & $6.67 \pm 5.56^{\mathrm{a}}$ & $83.33 \pm 4.44^{\mathrm{ab}}$ & $20.00 \pm 3.33^{\mathrm{a}}$ \\
\hline
\end{tabular}

Note: different letters indicate values that statistically significantly differ one from another within one line of the table according to the results of comparison by the Tukey test with Bonferroni correction at $\mathrm{P}<0.05$.

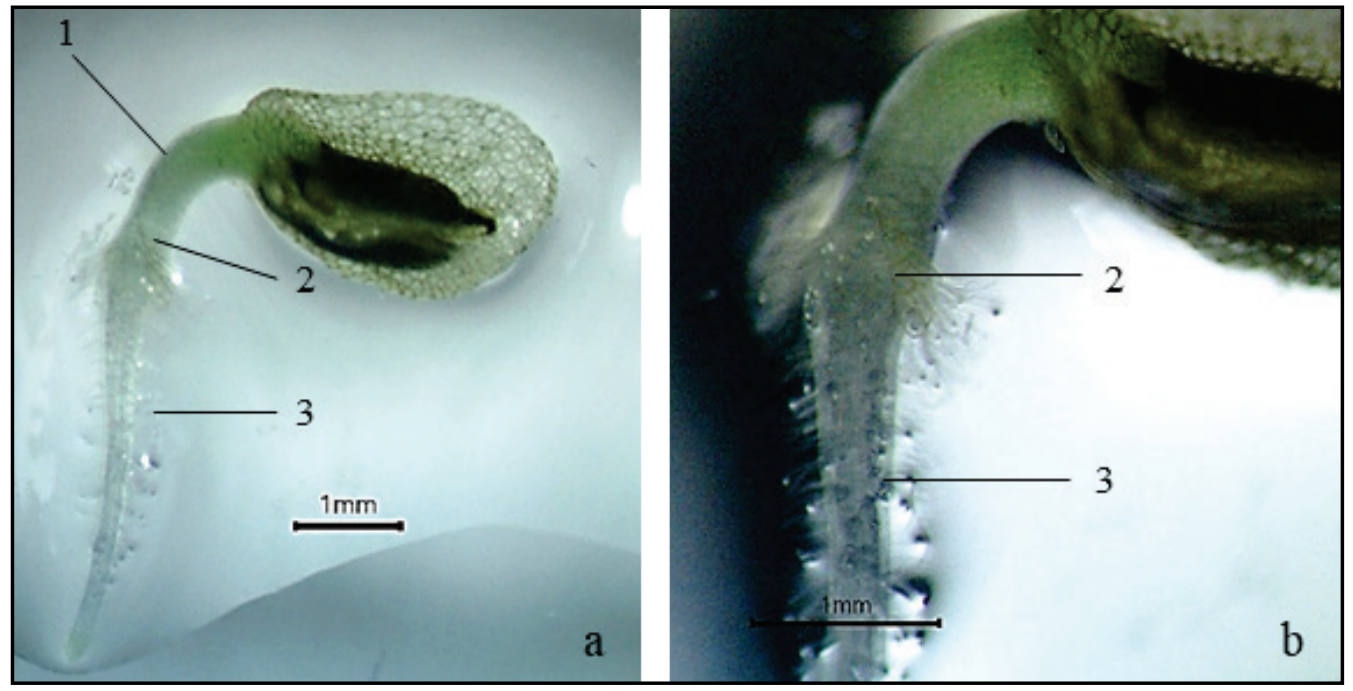

Fig. 2. Emergence of the main root and hypocotyl $(a)$ from the seed coating (well noticeable indumenta of thin root hairs on the main root and root neck, $b$ ): 1 -hypocotyls, 2 -root neck, 3 - the main root

At the same time, the main root begins to bend arch-like and quickly grows in length. On the 10-11th days after sowing of seeds, two cotyledons are released from the seed coating, which gradually, on 15-16 days stretch spatially. The cotyledons are green, elongated, with entire margins, on short petioles. At the initial stage of the development, in P. sceptrum- carolinum, they may be rounded, elongated, heart-shaped, more often oval-ovoid. The first assimilating leaf emerges on the 17-18th, the second - 22-24th days, and then the plant starts developing 1-2 lateral roots. The roots were short, filament-like, located spatially horizontally under a 90 degree angle in relation to the main root. 
In each of 5 variants of our experiments on growing $P$. sceptrumcarolinum from seeds in different experimental conditions in the course of two months, the plants that had grew had distinctive traits (Table 2). Therefore, during that period, the distinctive feature of the plants developing in Petri dishes (variant 1) was weak development of assimilating leaves, the sizes of which did not exceed $0.1 \mathrm{~cm}$ (Fig. 3, Table 2). Plants on the water surface (variant 2 ) were observed to have an extremely long hypocotyl, 2-8 times longer than in the other variants of the experiment and absence of lateral roots. During the development of plants in the groups of seeds sown in plastic containers (variant 3 ), despite the overall amount of assimilating leaves being the same as in the previous variants, the number of lateral roots was 4(8) times greater than in the rest of the experimental plants (Table 2). At the same time, on the lateral roots (variant 3), a fragmental development of haustorial hairs began, visually similar to the typical root hairs. Contrary to this, in variant 4 , we observed development of lateral haustoria of rounded shape (around $0.5 \mathrm{~mm}$ in diameter) on the lateral roots or in the basal part of the main root (Fig. 4). We should note that on the roots of some plants, three haustoria were developing at the same time, which were at different distances from one another. At the same time, haustoria of $P$. sceptrum-carolinum, in most cases, were located on the roots of Avena sativa near the tillering node, which led to gradual inhibition, and then death of the common oat. In seeds sown into soil singularly (variant 5 ), the main root practically completely rotted. On its short region, there usually remained one and more rarely up to three lateral roots. The development of short haustorial hairs on them was seen in singular cases. Furthermore, on a thickened region of the hypocotyl, there develops 1 , in extremely rare cases 3 adventitious roots. The number of assimilating leaves in this variant of the experiment (variant 5) was 2.5 times higher than in the groups of sown seeds (Table 2). Moreover, most of the plants (in all variants of the experiment) after two months growth were observed to have thickening of the hypocotyl and the basal part of the main root (if it remained), and the lower enlarged part of the leaf petioles became reddish.

Despite the fact that the plants had morphological differences in each particular variant of the experiment (Table 2), and also differences in the rates of the process of growth and development in each particular case, for the same time interval - two months, they all were characterized by formation of two cotyledons, 1-2 weakly developed long petiole leaves, root system comprising the main and adventitious roots of the first order (at the initial stage of the development, the adventitious roots were absent in some cases). The exception was variant 5 , where the number of developed green assimilating leaves in the plants was significantly higher than such in all the remaining variants of the experiments, the cotyledons died, and along with the lateral, there developed a small number of adventitious roots.

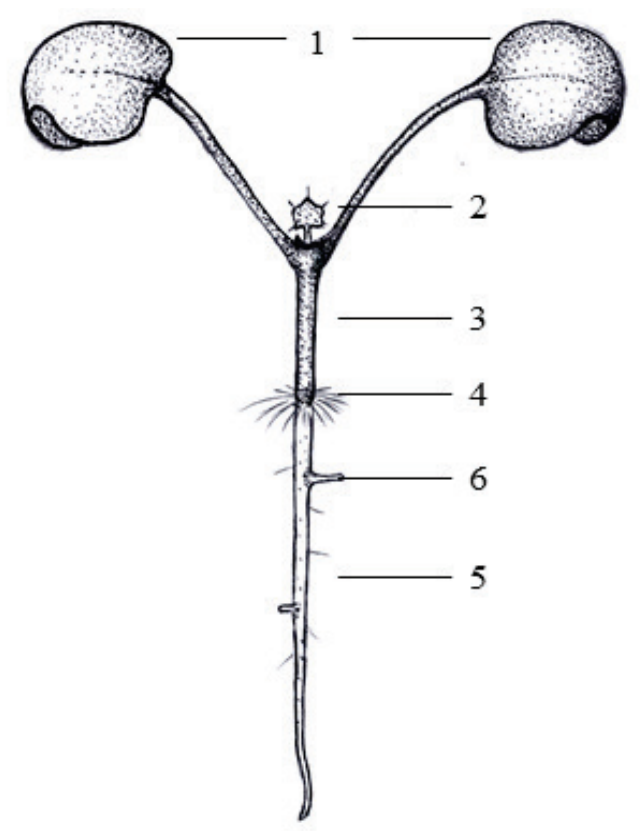

Fig. 3. Appearance of Pedicularis sceptrum-carolinum after two months growth in Petri dish: 1 - cotyledon leaves, 2 - assimilating leaf, 3 -hypocotyl, 4-root neck with indumentum of root hairs, 5 -main root, 6 - lateral root

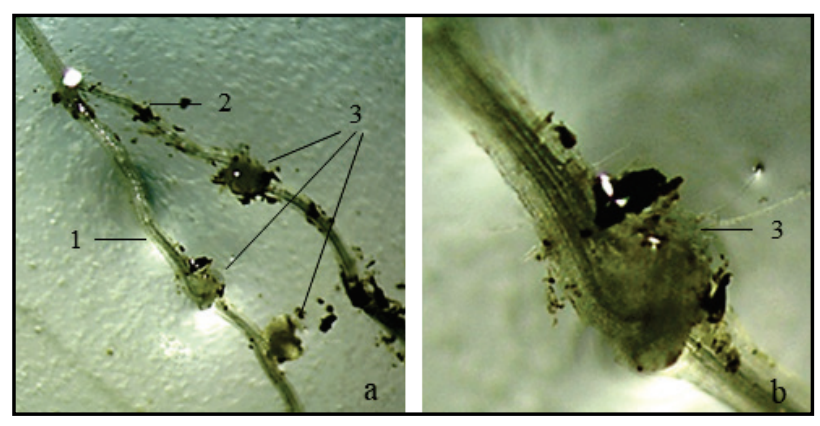

Fig. 4. Haustoria on the main and lateral roots of Pedicularis sceptrum-carolinum $(a)$; appearance of lateral haustorium $(b)$ : 1 - main root, 2 - lateral root, 3 - lateral haustoria

\section{Table 2}

The main morphometric parameters of Pedicularis sceptrum-carolinum plants grown from seeds in different conditions after two months of growth $(x \pm S D, n=5-10)$

\begin{tabular}{|c|c|c|c|c|c|}
\hline Main morphometric parameters of plant & $\begin{array}{c}\text { Experiment 1: } \\
\text { Plants grown } \\
\text { in Petri dishes on } \\
\text { moistened filter paper }\end{array}$ & $\begin{array}{c}\text { Experiment 2: } \\
\text { Plants grown in glass } \\
\text { vessels of } 300 \mathrm{~mL} \text { capaci- } \\
\text { ty with settled tap water }\end{array}$ & $\begin{array}{l}\text { Experiment 3: } \\
\text { Plants grown in } \\
\text { soil in plastic } \\
\text { container }\end{array}$ & $\begin{array}{c}\text { Experiment 4: } \\
\text { Plants grown in soil in plastic } \\
\text { contained together with seeds } \\
\text { of Avena sativa } \mathrm{L} \text {. }\end{array}$ & $\begin{array}{c}\text { Experiment } 5: \\
\text { Plants grown in soil, } \\
\text { one in plastic block } \\
\text { of } 9 \text { cassettes }\end{array}$ \\
\hline Total number of assimilating leaves & $1.10 \pm 0.85$ & $2.00 \pm 0.00$ & $2.00 \pm 0.33$ & $1.33 \pm 0.44$ & $4.75 \pm 0.90$ \\
\hline Total number of lateral roots & $2.00 \pm 0.00$ & - & $8.50 \pm 1.33$ & $1.00 \pm 0.66$ & $1.40 \pm 1.00(1.00 \pm 0.81)^{* *}$ \\
\hline Length of hypocotyl, in cm & $0.55 \pm 0.30$ & $1.60 \pm 0.20$ & $0.50 \pm 0.20$ & $0.50 \pm 0.20$ & $0.22 \pm 0.04$ \\
\hline Length of the main root, in $\mathrm{cm}$ & $1.46 \pm 0.44$ & $2.48 \pm 0.71$ & $2.10 \pm 0.63$ & $1.20 \pm 0.00$ & $0.30 \pm 0.00 * * *$ \\
\hline Maximum length of lateral roots, in $\mathrm{cm}$ & $0.35 \pm 0.10$ & - & $1.53 \pm 0.27$ & $0.85 \pm 0.25$ & $3.25 \pm 1.25(3.02 \pm 0.93) * *$ \\
\hline Length of cotyledon, in $\mathrm{cm}$ & $0.27 \pm 0.04$ & $0.25 \pm 0.06$ & $0.45 \pm 0.04$ & $0.34 \pm 0.02$ & - \\
\hline Width of cotyledon, in cm & $0.20 \pm 0.02$ & $0.13 \pm 0.02$ & $0.35 \pm 0.03$ & $0.25 \pm 0.03$ & - \\
\hline Length of petiole of the cotyledon, in $\mathrm{cm}$ & $0.56 \pm 0.06$ & $0.61 \pm 0.05$ & $0.36 \pm 0.04$ & $0.33 \pm 0.02$ & - \\
\hline Length of the $1^{\text {st }}$ leaf in $\mathrm{cm}$ & $*$ & $0.23 \pm 0.06$ & $0.53 \pm 0.10$ & $0.25 \pm 0.03$ & $0.57 \pm 0.14$ \\
\hline Length of the petiole of the $1^{\text {st }}$ leaf, $\mathrm{cm}$ & $*$ & $1.06 \pm 0.07$ & $0.98 \pm 0.12$ & $0.13 \pm 0.02$ & $0.54 \pm 0.13$ \\
\hline Length of the $2^{\text {nd }}$ leaf, $\mathrm{cm}$ & - & $0.11 \pm 0.03$ & $0.46 \pm 0.20$ & $0.30 \pm 0.10$ & $0.52 \pm 0.12$ \\
\hline Length of the petiole of the $2^{\text {nd }}$ leaf, $\mathrm{cm}$ & - & $0.90 \pm 0.04$ & $1.00 \pm 0.32$ & $0.25 \pm 0.14$ & $0.44 \pm 0.13$ \\
\hline Length of the $3^{\text {rd }}$ leaf, $\mathrm{cm}$ & - & - & - & - & $0.52 \pm 0.04$ \\
\hline Length of petiole of the $3^{\text {rd }}$ leaf, $\mathrm{cm}$ & - & - & - & - & $0.42 \pm 0.10$ \\
\hline Length of the $4^{\text {th }}$ leaf, cm & - & - & - & - & $0.50 \pm 0.13$ \\
\hline Length of petiole of the $4^{\text {th }}$ leaf, $\mathrm{cm}$ & - & - & - & - & $0.35 \pm 0.16$ \\
\hline
\end{tabular}

Note: “-“- organ is absent, *-sizes of the leaves are extremely small and do not exceed $0.1 \mathrm{~cm},{ }^{* *}$ - in round parentheses (in the corresponding lines), there is number and sizes of the adventitious roots, ${ }^{* * *}$ - residue of the main root. 
Unfortunately, we could not have observed the further development of the plants due to their gradual death. Plants that survived the longest (2.5 months) were the plants of moor-king lousewort in pure groups of sown seeds. Moor-king lousewort plants at that time were represented by rosette shoot with 4 (6) opposite long petiole leaves with enlarged base and rounded leaf laminae $(0.2-1.0 \mathrm{~cm}$ in diameter), divided into 57 rounded parts in wave-like pattern. On the laminae and petioles, there were indumenta of scattered glandular hairs. The cotyledons usually remained. The main root was well differentiated, vertical, quite strong, white, reaching on average 1.5-2.0 (2.5) $\mathrm{cm}$ length. The number of lateral roots increased 1.5-fold (up to 11-12), the vast majority of them ramified (up to order II), and singular ones locally bore haustorial hairs (Fig. 5). Despite such pattern of the development, with no visually seen threat to the plants and constant care for them, all of the plants ultimately died.

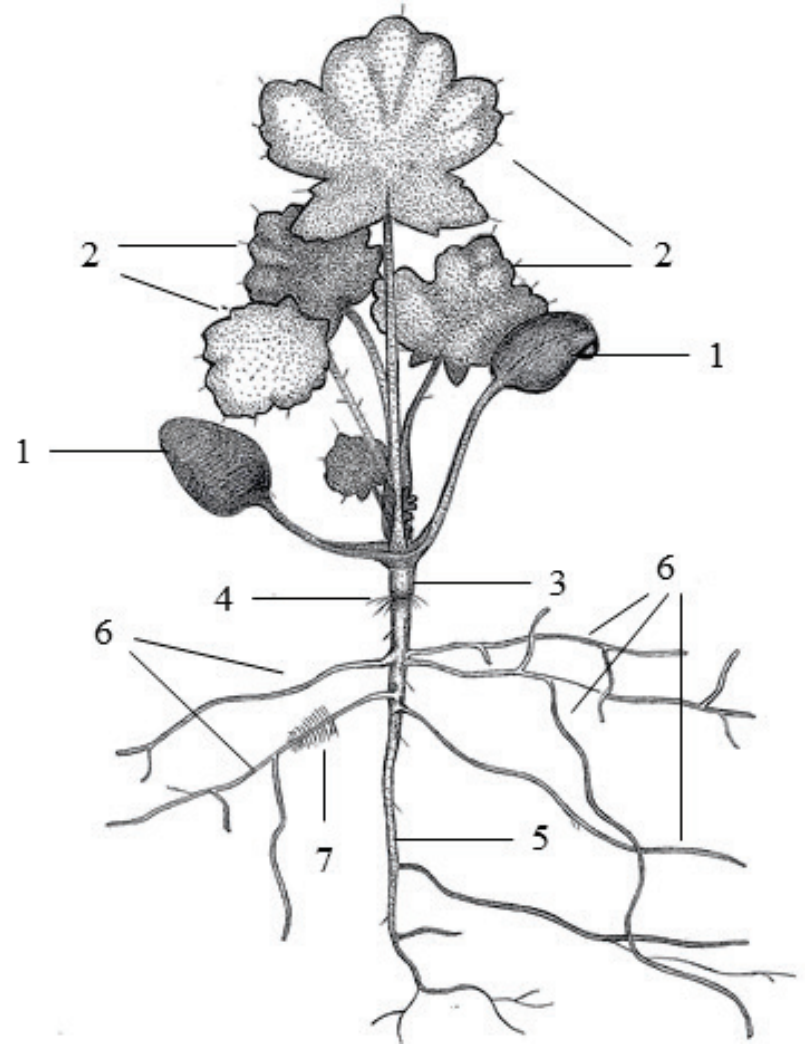

Fig. 5. Appearance of Pedicularis sceptrum-carolinum plant from groups of sown plants after 2.5 months growth: $1-6$, signs the same as in Fig. 3; 7 -haustorial hairs

\section{Discussion}

Seeds of most species of the Pedicularis L. genus are unable to germinate right after the harvest due to being in the state of physiological dormancy (Li et al., 2007). Among various methods of overcoming this type of dormancy, one of the common ones is after-ripening - the period (usually for several months) of dry storage of freshly harvested ripen seeds at room temperature (Probert, 2000; Finch-Savage \& Leubner-Metzger, 2006). Unfortunately, the use of this procedure for seeds of $P$. sceptrumcarolinum provided quite low values of the two most important parameters - final germination and energy of germination even in the conditions of long storage in laboratory conditions (Table 1). At the same time, regardless of whether the fruits contained seeds or not (in different periods of dry storage in the laboratory conditions), no significant differences between the corresponding parameters were observed. The same low percentage of germination (12.0 $\pm 5.7 \%$ and lower) as in our case was observed by the Chinese scientists (Ren \& Guan, 2008) in the experiments with seeds of three species of louseworts (Pedicularis rex C. B. Clarke ex Maxim., P. rhinanthoides Schrenk, and P. longiflora Rudolph), stored dry for one month in laboratory conditions.
Usually, to increase germination of seeds of representatives of the $\mathrm{Pe}$ dicularis genus, cold stratification is used, sometimes combined with other types of treatments (gibberellic acid, scarification, light, darkness) (Kaye et al., 1997; Li et al., 2007; Ren \& Guan, 2008; Serap et al., 2010; Belaeva et al., 2017). Therefore, for example, in freshly harvested seeds of $P$. sceptrum-carolinum picked up in late August of 2013-2014 in the vicinity of the Polar Alpine Botanical Garden (Kirovsk, Murmansk Oblast) in the foothills of Kukis Mountain along the road near waterlogged forest and in Sphagnum wetland and then subjected to humid cold stratification in a refrigerator (temperature $+4{ }^{\circ} \mathrm{C}$ ), germination varied $16 \%$ (2013) to $60 \%$ (2014) (Petrova \& Pavlenko, 2017). We found no research on the roles of dry stratification and low minus temperatures for increasing germination of seeds of this species in the literature sources.

The high parameters of final germination and energy of germination which we obtained after storing dry seeds in a refrigerator for three and six months (Table 1) indicate the effectiveness of such treatment. Different parameters were seen for seeds stored for the same time in a freezing chamber. A significant effect (though significantly lower than after storage in refrigerator) was also seen three months after storage in a freezing chamber (Table 1), which makes it significantly more different from the one obtained after longer maintenance in the same conditions. Increase in duration of maintenance in low minus temperatures likely causes the seeds to enter the state of secondary dormancy, causing rapid decrease in the main parameters of germination.

Research on the conditions needed for germination revealed that the germination of this species is adapted to the environmental conditions, for it is regulated by environmental factors (Van Assche et al., 2002). Knowledge of the conditions needed for germination of local species, especially rare species, is crucial for protection and restoration of biological diversity (Cerabolini et al., 2004). Furthermore, for threatened species, preservation of the components of biological diversity outside their natural habitats (ex situ preservation), growing plants from seeds, is considered a vital and cheap method (Serap et al., 2010). Taking into account that vegetative reproduction of $P$. sceptrum-carolinum is possible, but rarely takes place, and may occur only on small scales of one mother shoot, generative reproduction (as a system of reproduction and distribution by seeds) is essential for this species. At the same time, one needs to take into account that seeds of this plant have no morphological adaptations to spreading across large areas, but the fruits and shoots are sometimes eaten by animals that may be seed carriers across large distances (Wróblewska, 2013).

Difficulties with process of growing moor-king lousewort from seeds were seen earlier, because the species is unable to develop on its own for a long time at early stages of the development, even when added to reliably determined hosts (Petrova \& Pavlenko, 2017). As possible explanations of unsuccessful attempts to grow this plant from seeds, these scientists named damage to the root system of reliable host plants after transfer from the natural environment to the artificial, their nonadaptiveness to new conditions, and also presence of a particular specialization of $P$. sceptrumcarolinum to host plants. In our case, further gradual death of plants in all variants of the experiment after two-months growth, except pure groups of sown seeds (variant 3), was likely related not only to high mortality among seedlings (Petru, 2005). As some researchers indicate, seeds of the representatives of Pedicularis genus germinate regardless of host plants, and seedlings for their successful development at different stages require functional haustorial connections to the roots of host plants (Ter Borg, 1985; Růzicka, 1999 - quoted according to Petrů, 2005). The reason for failure of growing $P$. sceptrum-carolinum together with common oat is likely the certain selectivity of host plants, which is typical for this species (Petrova \& Pavlenko, 2017). Furthermore, death of plants in our experiment is likely related to deficiency of nutrients, intake of which is extremely sensitive for the growth of Pedicularis genus in the absence of host plants ( $\mathrm{Li}$ et al., 2013). It is especially relevant for nitrogen and phosphorus, especially because the latter element limits the growth of roots of hemiparasitic plants ( $\mathrm{Li}$ et al., 2013). Therefore, it is fair to say that more experiments are needed to seek the most productive conditions for growing $P$. sceptrum-carolinum. Successful experiments on growing some species of lousewort (P. rex and P. tricolor) in a greenhouse, conducted by the group of Chinese scientists (Li et al., 2013), confirm that growing hemiparasitic plants is quite possible. 


\section{Conclusions}

Taking into account the vulnerability of populations of $P$. sceptrumcarolinum and decrease in the number of locations of its growth, search for effective methods of its equal and fast germination with high germination percentage is essential for cultivating this plant and making it cultivatable. Our studies demonstrated that maximum value of the final germination may be achieved after keeping dry seeds of this plant in a refrigerator for 3 or 6 months. Knowledge of the conditions needed to grow the seeds of this plant would make it possible to predict the course of this process in conditions of land amelioration and drainage reclamation of wetlands, in cases of cold spells returning in early spring (low plus temperatures) or after minus temperatures in winter. Furthermore, the conditions needed for effective germination of seeds of $P$. sceptrum-carolinum which we found in our study will be useful for the future ex situ storage of this species.

Attempts to grow plants from seeds indicated that their development in experimental conditions is possible during 2.0-2.5 months. Longer period of their cultivation likely requires thorough selection of host plants, as well as storage conditions, taking into account complete provision of the plants at the early development stages with a set of nutrients needed for their growth and development.

The work was carried out within the framework of the State Assignment of the Ministry of Education and Science of the Russian Federation No. 121051100099-5.

\section{References}

Belaeva, T. N., Prokopyev, A. S., Butenkova, A. N., \& Astafurova, T. P. (2017) Pollination ecology and seed production of some species of the genus Pedicularis L. in the highlands of Altai. International Joumal of Environmental Studies, 74(5), 744-751.

Belyakov, E. A., \& Lapirov, A. G. (2015). Fruit germination of some representatives of the family Sparganiaceae Rudolphi under laboratory conditions. Inland Water Biology, 8(1), 33-37.

Bruce, W. R., Gladys, C., Frank, T., \& Kilpatrick, S. (2015). Phylogeny and biogeography of North American and Asian Pedicularis (Orobanchaceae). Systematic Botany, 40(1), 229-258.

Cerabolini, B., De Andreis, R., Ceriani, R. M., Pierce, S., \& Raimondi, B. (2004). Seed germination and conservation of endangered species from the Italian Alps: Physoplexis comosa and Primula glaucescens. Biological Conservation, 117(3), 351-356

Copenhaver, M. D., \& Holland, B. (1988). Computation of the distribution of the maximum studentized range statistic with application to multiple significance testing of simple effects. Joumal of Statistical Computation and Simulation, $30(1), 1-15$.

Danylevska, O. M., \& Futorna, O. A. (2016). Morfologichni osoblyvosti nasinyn vydiv rodu Pedicularis (Orobanchaceae) flory Ukrajiny [Morphological features of seeds of the Pedicularis (Orobanchaceae) species in the flora of Ukraine]. Ukrainian Botanical Journal, 73(5), 492-502 (in Ukrainian).

Finch-Savage, W. E., \& Leubner-Metzge, G. (2006). Seed dormancy and the control of germination. New Phytologist, 171(3), 501-523.

Hammer, Ø., Harper, D. A. T., \& Ryan, P. D. (2001). PAST: Paleontological Statistics Software Package for Education and Data Analysis. Palaeontologia Electronica, 4(1), 1-9.

Holub, J., \& Procházka, F. (2000). Red List of vascular plants of the Czech Republic-2000. Preslia, 72, 187-230.

Jensen, K. (2004). Dormancy patterns, germination ecology, and seed-bank types of twenty temperate fen grassland species. Wetlands, 24(1), 152-166.

Kaye, T. N., Liston, A., Love, R. M., Luoma, D. L., Meinke, R. J., \& Wilson, M. V. (1997). Seed dormancy in high elevation plants: Implications for ecology and restoration. Conservation and Management of Native Plants and Fungi. In: Proceedings of an Oregon Conference on the Conservation and Management of Native Vascular Plants, Bryophytes, and Fungi. Native Plant Society of Oregon Corvallis. Pp. 115-120.

Kirillova, N. R. (2018). Razvitie Pedicularis palustris L. (Orobanchaceae) na travyanyh bolotah Murmanskoj oblasti [Development of Pedicularis palustris L. (Oroban- chaceae) on grassy bogs of the Murmansk region]. Vestnik Murmanskogo Gosudarstvennogo Tekhnicheskogo Universiteta, 21(2), 199-206 (in Russian).

Kirmizi, S., Güleryüz, G., Arslan, H. F., \& Sakar, S. (2010). Effects of moist chilling, gibberellic acid, and scarification on seed dormancy in the rare endemic Pedicularis olympica (Scrophulariaceae). Turkish Journal of Botany, 34, 225-232.

Li, A.-R., Guan, K.-Y., \& Probert, R. J. (2007). Effects of light, scarification, and gibberellic acid on seed germination of eight Pedicularis species from Yunnan, China. HortScience, 42(5), 1259-1262.

Li, A.-R., Li, Y.-J., Smith, S. E., Smith, F. A., \& Guan, K.-Y. (2013). Nutrient requirements differ in two Pedicularis species in the absence of a host plant: Implication for driving forces in the evolution of host preference of root hemiparasitic plants. Annals of Botany, 112(6), 1099-1106.

Liu, M.-L., Yu, W.-B., Li, D.-Z., Mill, R. R., \& Hong, W. (2013). Seed morphological diversity of Pedicularis (Orobanchaceae) and its taxonomic significance. Plant Systematics and Evolution, 299(9), 1645-1657.

Maglocký, S.., \& Feráková, V. (1993). Red list of ferns and flowering plants (Pteridophyta and Spermatophyta) of the flora of Slovakia (the second draft). Biologia, 48(4), 361-385.

McDonough, W. T. (1970). Germination of 21 species collected from a high-elevation rangeland in Utah. The American Midland Naturalist, 84(2), 551-554.

Nikolaeva, M. G., Lyanguzova, I. V., \& Pozdova, L. M. (1999). Biologiya semyan [Biology of Seeds]. Research Institute of Chemistry of Saint-Petersburg State University, Saint-Petersburg (in Russian).

Peregrym, O. M., \& Peregrym, M. M. (2014). Poshyrennia vydiv rodu Pedicularis (Orobanchaceae) v Ukrajini [Distribution of species of the genus Pedicularis (Orobanchaceae) in Ukraine]. Ukrainian Botanical Journal, 71(5), 573-580 (in Ukrainian).

Petrova, S. E., \& Pavlenko, E. V. (2017). Biologiya i morfologo-anatomicheskie osobennosti Pedicularis sceptrum-carolinum (Scrophulariaceae) s. 1. (Hibiny) [Biology and morphological and anatomical features of Pedicularis sceptrum-carolinum (Scrophulariaceae) s.l. (Khibiny)]. Botanical Joumal, 102(4), 526-539 (in Russian).

Petrů, M. (2005). Year-to-year oscillations in demography of the strictly biennial Pedicularis sylvatica and effects of experimental disturbances. Plant Ecology, 181(2), 289-298.

Probert, R. J. (2000). The role of temperature in the regulation of seed dormancy and germination. In: Seeds. The ecology of regeneration in plant communities. CABI International, Wallingford. Pp. 261-292.

Ree, R. H. (2005). Phylogeny and the evolution of floral diversity in Pedicularis (Orobanchaceae). International Joumal of Plant Sciences, 166(4), 595-613.

Ren, Y.-Q., \& Guan, K.-Y. (2008). Effects of moist-chilling and GA3 applications on seed germination of three Pedicularis species from Yunnan, China. Seed Science and Technology, 36(1), 225-229.

Serap, K., Gürcan, G., Hülya, A., \& Selcen, S. F. (2010). Effects of moist chilling, gibberellic acid, and scarification on seed dormancy in the rare endemic Pedicularis olympica (Scrophulariaceae). Turkish Journal of Botany, 34(3), 225-232.

Seregin, A. P. (2011). Pedicularis palustris i P. sceptrum-carolinum (Orobanchaceae) vo Vladimirskoj oblasti i v Srednej Rossii: Dinamika i prichiny vymiraniya [Pedicularis palustris and P. sceptrum-carolinum (Orobanchaceae) in the Vladimir Region and Central Russia: Dynamics and causes of extinction]. Botanical Journal, 96(12), 1561-1574 (in Russian).

Shipley, B., \& Parent, M. (1991). Germination responses of 64 wetland species in relation to seed size, minimum time to reproduction and seedling relative growth rate. Functional Ecology, 5(1), 111-118.

Sorokin, A. S. (2016). Mytnik skipetrovidnyj [Pedicularis sceptrum-carolinum L.]. In: Orlov, S. V., Sokolov, D. L., Perova, I. S., Kokina, O. M., Turilov, A. V., \& Vedernikova, E. S. (ed.). The Red Book of Tver region. Tver Printing Yard, Tver. P. 123 (in Russian).

Stachurska-Swakon, A., Wołkowycki, D., \& Kucharczyk, M. (2014). EN-Pedicularis sceptrum-carolinum L. - Gnidosz królewski. In: Polish Red Data Book of Plants. Pteridophytes and flowering plants. Institute of Nature Conservation Polish Academy of Sciences, Krakow. Pp. 454 456.

Van Assche, J., Van Nerum, D., \& Darius, P. (2002). The comparative germination ecology of nine Rumex species. Plant Ecology, 159(2), 131-142.

Voronin, L. V. (2015). Mytnik skipetrovidnyj [Pedicularis sceptrum-carolinum L.]. In: Nyankovsky, M. A. (Ed.). The Red Book of Yaroslavl region. Academy 76 , Yaroslavl. P. 198 (in Russian).

Wróblewska, A. (2013). Genetic diversity within populations of Pedicularis sceptrum-carolinum. Annales Botanici Fennici, 50(5), 289-299.

Wróblewska, A., \& Mirski, P. (2018). From past to future: impact of climate change on range shifts and genetic diversity patterns of circumboreal plants. Regional Environmental Change, 18(2), 409-424. 